\title{
Pengembangan Perangkat Pembelajaran untuk Meningkatkan Kemampuan Berpikir Kreatif Siswa Sekolah Dasar
}

\author{
Mahlianurrahman \\ STKIP Bina Bangsa Meulaboh Aceh Barat \\ Sbsrahman@yahoo.com/Rahmanklut@gmail.com
}

\begin{abstract}
This study aims to (1) produce a SETS kit that is feasible to the creative thinking of Elementary School (2) find out the effectiveness of the SETS kit to the creative thinking. This study is a research and development refering to the opinion of Borg \& Gall. The design of learning kits consists of 9 steps, including (1) research and information collection; (2) planning; (3) developing preliminary form of draft product; (4) preliminary field testing; (5) main product revision; (6) main field testing; (7) operational product testing; (8) operational field testing; and (9) final product revision. Subjects were students of Elementary School 3 Kota Fajar. The results show that the learning kit is effective to creative thinking of students according to the material expert and learning expert with excellent ratings category. Based on the result show that there are significant differences in creative thinking of students who take the study with SETS kits with those who do not use learning kits.
\end{abstract}

Keywords: SETS Kits and Creative Thinking.

Abstrak: Penelitian ini bertujuan untuk menghasilkan perangkat pembelajaran SETS yang layak, untuk meningkatkan kemampuan berpikir kreatif siswa dan mengetahui keefektifan perangkat pembelajaran SETS. Penelitian ini merupakan penelitian dan pengembangan mengacu pendapat Borg \& Gall. Desain pengembangan perangkat pembelajaran ini meliputi 9 langkah, yaitu (1) penelitian pendahuluan dan pengumpulan informasi; (2) perencanaan; (3) pengembangan draft produk; (4) uji coba awal; (5) merevisi hasil uji coba terbatas; (6) uji coba lapangan; (7) penyempurnaan produk hasil uji coba lapangan; (8) uji coba lapangan operasional; dan (9) penyempurnaan produk akhir. Subjek penelitian adalah siswa SD Negeri 3 Kotafajar. Hasil penelitian menunjukkan bahwa perangkat pembelajaran layak digunakan menurut ahli materi dan ahli pembelajaran dengan kategori sangat baik. Berdasarkan hasil penelitian diketahui, bahwa terdapat perbedaan yang signifikan terhadap kemampuan berpikir kreatif antara siswa yang mengikuti pembelajaran dengan perangkat pembelajaran SETS dan yang tidak menggunakan perangkat pembelajaran hasil pengembangan.

Kata Kunci: Perangkat Pembelajaran SETS, Berpikir Kreatif

Ar-Riayah : Jurnal Pendidikan Dasar vol.1 no. 01, 2017

STAIN Curup - Bengkulu I p ISSN 2580-362X; e ISSN 2580-3611 



\section{Pendahuluan}

Meningkatkan sumber daya manusia yang berkarakter baik dapat dilakukan dengan memperbaiki sistem pendidikan. Langkah awal memperbaiki sistem pendidikan dapat dilakukan dengan pengadaaan sarana pembelajaran, menjalin kerjasama yang baik antara guru dengan orang tua, penyempurnaan kurikulum, dan meningkatkan kualitas guru melalui penyelenggaraan berbagai pelatihan. Guru yang berkualitas dapat terlihat dari kemampuan guru dalam menyampaikan materi saat proses pembelajaran. Penyampaian materi tidak hanya dianggap sekedar tuntutan atau tugas yang harus dilakukan dan diselesaikan setiap harinya, melainkan adanya interaksi antara siswa dan guru dalam menggapai tujuan pembelajaran.

Undang-Undang Republik Indonesia Nomor 20 Tahun 2003 tentang Sistem Pendidikan Nasional menyebutkan bahwa pendidikan bertujuan mengembangkan potensi peserta didik agar menjadi manusia beriman, bertaqwa kepada Tuhan Yang Maha Esa, berakhlak mulia, sehat berilmu, cakap, kreatif, mandiri dan menjadi warga negara demokratis serta bertanggungjawab. Guna tercapainya acuan utama pendidikan, hal yang penting adalah Standar Proses yang tertuang dalam Peraturan Menteri Pendidikan Nasional Nomor 41 tahun 2007. Standar proses untuk satuan pendidikan dasar dan menengah mencakup perencanaan proses pembelajaran, pelaksanaan proses pembelajaran, penilaian hasil pembelajaran, dan pengawasan proses pembelajaran. dalam perencanaan termasuk di dalamnya adalah silabus dan RPP.

Salah satu penanda tercapainya tujuan pembelajaran adalah siswa mampu meningkatkan kemampuan berpikir kreatif yang kemudian diterapkan pada kehidupan sehar-hari. Kemampuan berpikir kreatif merupakan hal yang paling mendasar dalam pembelajaran Ilmu Pengetahuan Alam (IPA). Berpikir kreatif tidak hanya sebatas kemampuan mengingat dan menghafal, akan tetapi 
mampu menjelaskan dan mengaplikasikan hasil pemikiran kedalam kehidupan sehari-hari, karena dalam pembelajaran IPA di Sekolah Dasar (SD) berpikir kreatif merupakan unsur yang sangat penting.

Dalam kegiatan pembelajaran, siswa yang memiliki kemampuan berpikir kreatif dapat membantu siswa lainnya yang mengalami masalah dalam memahami materi pelajaran. Pengembangan kemampuan berpikir kreatif memang perlu dilakukan karena kemampuan ini merupakan salah satu kemampuan yang dikehendaki dunia kerja.Tidak diragukan lagi bahwa kemampuan berpikir kreatif juga menjadi penentu keunggulan suatu bangsa. Daya kompetitif suatu bangsa sangat ditentukan oleh kreativitas sumber daya manusianya. Pembelajaran IPA perlu dirancang sedemikian rupa sehingga berpotensi mengembangkan kemampuan berpikir kreatif siswa. Pengembangan kemampuan berpikir kreatif perlu dilakukan seiring dengan pengembangan cara mengevaluasi atau cara mengukurnya.

Apabila siswa dihadapkan pada suatu masalah yang harus dipecahkan, maka siswa tersebut memiliki kemampuan untuk menginterpretasikan ide, membandingkan, membedakan, memecahkan permasalahan tersebut, dan membuat kesimpulan, maka siswa tersebutlah yang dikatakan memiliki berpikir kreatif. Kemampuan berpikir kreatif merupakan komponen penting dan komponen ini harus ditonjolkan dalam proses pembelajaran, karena kemampuan berpikir kreatif merupakan bagian dari ranah kognitif yang merupakan tujuan kegiatan belajar mengajar.

Siswa tidak hanya dituntut untuk paham terhadap materi akan tetapi siswa juga harus mampu menjelaskan makna dari materi sehingga siswa dapat mengarah pada taraf menerapkan materi yang dipahami dalam kehidupan seharihari. Selain paham terhadap materi IPA, siswa juga harus memiliki kemampuan berpikir kreatif. 
Berdasarkan hasil wawancara dengan guru SD Negeri 3 Kota Fajar, diperoleh informasi bahwa guru tidak menyusun perangkat pembelajaran melainkan hanya menyalin perangkat pembelajaran pada tahun ajaran sebelumnya dan masih ada guru yang berpedoman pada perangkat yang digunakan sejak tahun 2013. Guru sangat membutuhkan perangkat pembelajaran yang mendukung untuk meningkatkan kemampuan berpikir kreatif. Selain itu, guru juga tidak memahami pendekatan Science, Environment, Technology And Society (SETS). Hal tersebut tentu saja mengakibatkan guru tidak mampu membuat perangkat pembelajaran dengan pendekatan pembelajaran SETS yang dapat meningkatkan kemampuan berpikir kreatif.

Pembelajaran IPA di SD N 3 Kota Fajar sejauh ini masih didominasi pembelajaran konvensional dengan paradigma guru mengajar hanya berorientasi pada hasil belajar yang dapat diamati dan diukur. Siswa pasif dan guru cenderung memindahkan informasi sebanyak-banyaknya kepada siswa sehingga konsep, prinsip dan aturan-aturan sulit dipahami oleh siswa. Pembelajaran seperti ini tentunya akan berakibat buruk pada prestasi belajar siswa-siswa SD N 3 Kota Fajar, hal ini terbukti dari hasil observasi di sekolah tersebut.

Guru harus mampu menggunakan berbagai pendekatan pembelajaran agar siswa dapat melakukan kegiatan belajar dengan menyenangkan. Hal ini dilatar belakangi bahwa siswa bukan hanya sebagai obyek tetapi juga merupakan subyek dalam pembelajaran. Siswa harus disiapkan sejak awal untuk mampu bersosialisasi dengan lingkungannya sehingga berbagai jenis pendekatan pembelajaran dapat digunakan oleh peserta. Guru seharusnya tidak mendominasi kegiatan pembelajaran, siswa hanya duduk, diam, mendengarkan, mencatat, dan mentaati segala perlakuan guru.

Kenyataannya masih banyak guru yang sulit merubah pola pikir dari teaching menjadi learning. Guru masih mendominasi proses pembelajaran dan 
siswa hanya sebagai objek. Pembelajaran IPA yang selama ini dilaksanakan cenderung menggunakan pendekatan yang kurang tepat. Guru lebih banyak menggurui daripada sebagai fasilitator, dan tidak mengacu pada program pembelajaran yang disusun. Selama proses pembelajaran guru jarang menyampaikan standar kompetensi, guru hanya sekedar mengingatkan siswa tentang materi pertemuan sebelumnya, kemudian guru melanjutkan materi yang akan diberikan. Setelah selesai menjelaskan, guru melanjutkan dengan memberikan soal latihan yang ada di buku.

Rencana Pelaksanaan Pembelajaran (RPP) dan Lembar Kerja Siswa (LKS) yang dimiliki guru hanya menyalin RPP dan LKS tahun sebelumnya. Hal tersebut terlihat dari arsip RPP dan LKS pada tahun sebelumnya dan adanya kesalahan-kesalahan penulisan tahun pada RPP dan LKS. Masih ada siswa mengikuti pembelajaran yang kurang aktif, meskipun proses pembelajaran telah dilaksanakan secara berkelompok akan tetapi pengelompokan tersebut kurang efektif karena tidak tercantumnya langkah-langkah pembelajaran di dalam RPP. Masih ada siswa yang membuang sampah sembarangan, mencabut tanaman di Taman, mencoret meja dan dinding, serta masih ada siswa yang tidak mau piket harian.

Ketika proses pembelajaran hanya fokus pada hasil belajar sebagai indikator ketuntasan belajar, masih didominasi oleh guru sebagai sumber utama pengetahuan, proses pembelajaran yang kurang bervariasi, dan tidak memiliki pendekatan pembelajaran saat mengajar, maka siswa kurang tertarik, kurang berminat dan tidak fokus pada proses pembelajaran yang sedang berlangsung, siswa kurang mendapat kesempatan untuk menggali pengetahuan dan mengaitkan konsep yang dipelajari. Pembelajaran yang kondisinya seperti ini, guru harus mampu merancang perangkat pembelajaran yang menjadikan siswa memiliki kemampuan berpikir kreatif. 
Hasil analisis perangkat pembelajaran yang digunakan guru menunjukkan bahwa guru belum memasukkan pendekatan pembelajaran SETS ke dalam perangkat pembelajaran. Perangkat pembelajaran yang dibuat oleh guru hanya merujuk pada buku guru dan hanya sebatas materi yang ada di buku siswa. Dengan kata lain, belum ada pengembangan perangkat pembelajaran yang di dalamnya terdapat pendekatan pembelajaran SETS. Pembelajaran yang menerapkan pendekatan pembelajaran SETS diharapakan dapat menjadikan pembelajaran lebih menyenangkan dan bermakna bagi siswa serta dapat meningkatkan kemampuan berpikir kreatif.

Stephen A. M., \& Megan Doidge : “An STS approach which deals with issues related to learners' lives aims to make science relevant to their daily lives, promote responsible decisionmaking and citizenship and thereby developing scientific literacy".

Meningkatkan kemampuan berpikir kreatif, maka diperlukan suatu pendekatan pembelajaran yang kontekstual, yaitu pendekatan pembelajaran SETS. Adapun ciri-ciri Pendekatan SETS adalah pembelajaran yang mengaitkan anatara sains dengan teknologi, lingkungan dan masyarakat, serta memberikan pengalaman belajar bagi siswa dalam mengidentifikasi masalah, mengumpulkan data, mempertimbangkan solusi alternatif, dan mempertimbangkan berdasarkan keputusan tertentu. Sebagaimana penjelasan Bernadete I. D. R., bahwa "an approach using the interactions of four important factors, namely: science, technology, society and environment. Using activities derived from the local environment, a learning climate unique to the STSE approach was developed and used to determine its influence on academic

${ }^{1}$ Stephen, A.M., \& Megan D., The Impact of an STS Approach on the Development of Aspects of Scientific Literacy of Grade 10 Learners, (Paper presented at SAARMSTE Conference, 2012), 1.1.

Ar-Riayah : Jurnal Pendidikan Dasar vol.1 no. 01, 2017

STAIN Curup - Bengkulu I p ISSN 2580-362X; e ISSN 2580-3611 
acbievement and environmental science self-efficacy of students as well as their sociocultural perspectives. $^{2}$

Penelitian ini akan mengembangkan perangkat pembelajaran SETS, diharapkan dapat memberikan manfaat yang lebih dibandingkan dengan pembelajaran yang menerapkan pendekatan konvensional dan dapat mempermudah guru dalam melaksanakan proses pembelajaran sehingga ketercapaian tujuan pembelajaran lebih maksimal. Proses pembelajaran yang diterapkan telah sesuai dengan tahapan pendekatan pembelajaran SETS, yaitu: 1) Tahap invitasi, meliputi pengamatan hal yang menarik dari lingkungan sekitar yang berkaitan dengan materi yang akan dipelajari kemudian mengajukan pertanyaan-pertanyaan mengenai hal tersebut; 2) Tahap eksplorasi, pada tahap eksplorasi siswa memberikan sumbang saran alternatif yang sesuai tentang informasi yang akan dicari, mengobservasi fenomena khusus, mengumpulkan data, memecahkan masalah, dan menganalisis data; 3) Tahap pengajuan penjelasan dan solusi, meliputi kegiatan menyampaikan gagasan, menyusun model, membuat penjelasan baru, membuat solusi, dan memadukan solusi dengan teori dan pengalaman; 4) Tahap penentuan langkah, tahap dimana siswa membuat keputusan, menggunakan pengetahuan dan keterampilan, berbagi informasi, gagasan, dan mengajukan pertanyaan lanjutan. ${ }^{3}$

Perangkat pembelajaran untuk meningkatkan kemampuan berpikir kreatif belum dikembangkan di SDN 3 Kota Fajar, sehingga akan sangat bermanfaat dan dapat digunakan untuk memenuhi kebutuhan guru. Berdasarkan penjelasan tersebut, hal yang sangat dibutuhkan dalam rangka meningkatkan

2 Bernadete, I.D.R, Science, Technology, Society and Environment (STSE) Approach in Environmental Science for Nonscience Students in a Local Culture, Journal of Higher Education Research Science and Technology Section $6: 2009,281$.

${ }^{3}$ Mariana \& Alit, M, Suatu Tujuan Tentang Hakikat Pendekatan Science, Technology, and Society dalam Pembelajaran Sain, (Pelangi Pendidikan, 2, 2000). 40- 41. 
kemampuan berpikir kreatif adalah perangkat pembelajaran yang menjadi acuan guru untuk mengajar.

\section{Metode}

Penelitian ini menggunakan model penelitian dan pengembangan dari Gall, Gall, \& Borg. Tetapi, penelitian ini hanya dilaksanakan sampai pada tahap kesembilan, yaitu: (1) penelitian pendahuluan dan pengumpulan informasi, (2) perencanaan, (3) pengembangan draf produk, (4) uji coba terbatas, (5) merevisi hasil uji coba terbatas, (6) uji coba lapangan, (7) penyempurnaan produk hasil uji coba lapangan, (8) uji coba lapangan operasional, dan (9) penyempurnaan produk akhir. ${ }^{4}$

\section{Desain Uji Coba Produk}

Uji coba produk terdiri atas tiga tahap yaitu uji coba terbatas, uji coba lapangan dan uji coba lapangan operasional. Sebelum uji coba, produk perangkat pembelajaran divalidasi oleh ahli materi dan ahli pembelajaran. Subjek uji coba dalam penelitian ini adalah siswa kelas IV SDN 3 Kota Fajar. Sebanyak 4 siswa untuk uji coba terbatas, dan 7 siswa untuk uji coba lapangan dan seluruh siswa Kelas IV sebagai uci coba lapangan operasional.

\section{Instrumen Pengumpulan Data}

Pada penelitian ini, instrumen penelitian yang digunakan adalah penilaian RPP, penilaian LKS, skala respon guru dan respon siswa.

\section{Teknik Analisis Data}

Data sebelum pelaksanaan penelitian dalam bentuk hasil wawancara, observasi, studi pustaka, dan analisis perangkat pembelajaran yang digunakan oleh guru sebagai analisis kebutuhan (need analysis) pengembangan perangkat pembelajaran. Data tersebut dianalisis menggunakan teknik analisis data

${ }^{4}$ Gall, M. D., Gall, J. P., \& Borg, W. R, An Introduction to Educational Design Research. East, 129. Retrieved from www.slo.nl/organisatie/international/publications. 2007.

Ar-Riayah : Jurnal Pendidikan Dasar vol.1 no. 01, 2017

STAIN Curup - Bengkulu I p ISSN 2580-362X; e ISSN 2580-3611 
kualitatif berdasarkan pendapat Miles, M.B., Huberman, A.M., \& Saldana, J. yang meliputi tiga tahap, yaitu, data condensation (kondensasi data), data dis-play (penyajian data), dan conclusion drawing/ verification (penarikan kesimpulan/ verifikasi). ${ }^{5}$

Data setelah penelitian berupa data kuantitatif dianalisis untuk mendapatkan perangkat pembelajaran yang layak dan efektif. Kelayakan produk yang dihasilkan dianalisis dengan persentase. Penilaian dikatakan memenuhi kriteria jika kategori minimal yang dicapai adalah baik. Kelayakan produk yang dihasilkan dianalisis dengan rumus di bawah ini : ${ }^{6}$

$$
\text { Nilai }=\frac{\text { Skor Perolehan }}{\text { Skor Maksimal }} \times 100 \%
$$

Kriteria kualitas perangkat pembelajaran yang dikembangkan diadaptasi dari pendapat yang dapat dilihat pada tabel 1 berikut ini :?

Tabel 1.

Kriteria Kualitas Perangkat Pembelajaran

\begin{tabular}{clll}
\hline Nilai & \multicolumn{3}{c}{ Predikat } \\
\hline $85,01-100,00 \%$ & $\begin{array}{l}\text { Sangat valid (dapat digunakan tanpa } \\
\text { revisi) }\end{array}$ & \\
\hline $70,01-85 \%$ & $\begin{array}{l}\text { Cukup valid (saat digunakan perlu } \\
\text { direvisi kecil) }\end{array}$ & \\
\hline $50,01-70 \%$ & Kurang valid (disarankan tidak \\
& digunakan karena perlu revisi banyak) \\
\hline $01-50 \%$ & Tidak valid (tidak boleh digunakan) \\
\hline
\end{tabular}

${ }^{5}$ Miles, M.B., Huberman, A.M., \& Saldana, J, Qualitative Data Analysis : A Methods Sourcebook, (Los Angeles: Sage, 2014), 12. 82.

${ }^{6} \mathrm{Akbar}, \mathrm{S}$, Instrumen Perangkat Pembelajaran, (Bandung : PT Remaja Rosdakarya, 2013),

${ }^{7}$ Ibid., 155. 


\section{Hasil dan Pembahasan}

Berdasarkan hasil wawancara dengan guru, diperoleh informasi bahwa guru tidak menyusun perangkat pembelajaran, melainkan hanya menyalin perangkat pembelajaran tahun-tahun sebelumnya. Guru juga menyampaikan bahwa sangat membutuhkan perangkat pembelajaran yang dapat dijadikan pedoman untuk meningkatkan kemampuan berpikir kreatif. Selain melalui wawancara, informasi juga didapat melalui observasi untuk mengetahui gambaran awal tentang proses pembelajaran beserta perangkat pembelajaran yang digunakan.

Proses pembelajaran siswa sudah dikondisikan untuk belajar secara berkelompok. Namun, pembagian kelompok kurang bervariasi. Selain itu, masih adanya kompetisi antar siswa dalam satu kelompok maupun kompetisi antar kelompok. Adanya kompetisi inilah yang menjadi salah satu penyebab sikap egois siswa, kurang peduli terhadap teman, bahkan menyebabkan rendahnya kreativitas siswa, sehingga pembelajaran secara berkelompok yang telah diterapkan kurang efektif.

Pada tahap studi pustaka, peneliti melakukan kajian terhadap teori tentang perangkat pembelajaran, pendekatan SETS dan kemampuan berpikir kreatif. Kegiatan yang dilakukan adalah dengan menganalisis buku-buku dan jurnal. Kajian buku dan jurnal yang dianalisis adalah mengenai perangkat pembelajaran yang meliputi RPP, LKS, pendekatan SETS, dan kemampuan berpikir kreatif. Tahap analisis perangkat pembelajaran, dapat diketahui bahwa perangkat pembelajaran yang digunakan belum sesuai dengan kebutuhan untuk meningkatkan kemampuan berpikir kreatif. Hasil studi pendahuluan dapat disimpulkan bahwa guru tidak membuat perangkat pembelajaran yang sesuai dengan tujuan pembelajaran, yaitu meningkatkan kemampuan berpikir kreatif. 
Maka penelitian ini difokuskan untuk mengembangkan perangkat pembelajaran SETS untuk meningkatkan kemampuan berpikir kreatif siswa kelas IV SD.

\section{Data Hasil Validasi Ahli}

Data hasil penilaian produk perangkat pembelajaran yang dilakukan oleh ahli materi dan ahli pembelajaran secara lengkap dapat dilihat pada Tabel 2 dan 3 berikut ini:

Tabel 2.

Data Hasil Penilaian Perangkat Pembelajaran Oleh Ahli Materi

\begin{tabular}{cccc}
\hline No & $\begin{array}{c}\text { Perangkat } \\
\text { Pembelajaran }\end{array}$ & Persentase & $\begin{array}{c}\text { Kategori } \\
\text { Kelayakan }\end{array}$ \\
\hline 1 & RPP & 90,75 & Valid \\
2 & LKS & 88,50 & Valid \\
\hline
\end{tabular}

Ahli pembelajaran memberikan penilaian sebesar 90,75, untuk RPP dan LKS sebesar 88,50. Ini juga berarti bahwa perangkat pembelajaran layak digunakan setelah revisi.

Tabel 3.

Data Hasil Penilaian Perangkat Pembelajaran Oleh Ahli Materi

\begin{tabular}{cccc}
\hline No & $\begin{array}{c}\text { Perangkat } \\
\text { Pembelajaran }\end{array}$ & Persentase & $\begin{array}{c}\text { Kategori } \\
\text { Kelayakan }\end{array}$ \\
\hline 1 & RPP & 91,20 & Valid \\
2 & LKS & 89,45 & Valid \\
\hline
\end{tabular}

Data hasil penilaian produk oleh ahli materi diperoleh persentase untuk RPP sebesar 91,20, untuk LKS 89,45. Artinya, perangkat pembelajaran layak digunakan setelah revisi.

\section{Analisis Data Hasil Uji Coba Terbatas}


Adapun penilaian kemampuan berpikir kreatif setelah mengikuti pembelajaran menggunakan perangkat pembelajaran hasil pengembangan dapat dilihat pada tabel 4 dan 5 berikut ini:

Tabel 4.

Hasil Uji Coba Terbatas Sebelum Mengikuti Pembelajaran

\begin{tabular}{cc}
\hline $\begin{array}{c}\text { Sebelum Mengikuti } \\
\text { Pembelajaran }\end{array}$ & Persentase \\
\hline $\begin{array}{c}\text { Kemampuan Berpikir } \\
\text { Kreatif }\end{array}$ & 60,40 \\
\hline
\end{tabular}

Sebelum mengikuti pembelajaran dengan menggunakan perangkat pembelajaran SETS, rata-rata skor kemampuan berpikir kreatif siswa sebesar 60,40 .

Tabel 5.

Hasil Uji Coba Terbatas Setelah Mengikuti Pembelajaran

\begin{tabular}{cc}
\hline $\begin{array}{c}\text { Setelah Mengikuti } \\
\text { Pembelajaran }\end{array}$ & Persentase \\
\hline Kemampuan Berpikir & 68,50 \\
Kreatif & \\
\hline
\end{tabular}

Setelah mengikuti pembelajaran yang dimaksud, rata-rata skor kemampuan berpikir kreatif siswa adalah 68,50.

\section{Analisis Data Hasil Uji Coba Lapangan}

Berikut diagram yang menggambarkan peningkatan kemampuan berpikir kreatif siswa pada uji coba lapangan :

Gambar 1.

Perbandingan Hasil Kemampuan Berpikir Kreatif Uji Coba Lapangan 


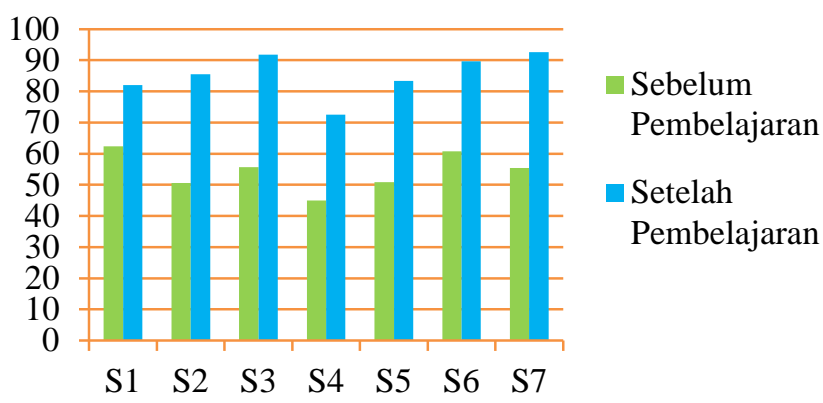

Grafik di atas menunjukkan peningkatan kemampuan berpikir kreatif dari 7 siswa sebagai subyek uji coba lapangan. Skor kemampuan berpikir kreatif siswa setelah mengikuti pembelajaran lebih tinggi dibandingkan skor kemampuan berpikir kreatif sebelum mengikuti pembelajaran.

\section{Analisis Data Hasil Uji Coba Lapangan Operasional}

Perolehan skor kemampuan berpikir kreatif kelas eksperimen pada uji coba lapangan operasional termasuk dalam kategori sangat baik. Adapun hasil kemampuan berpikir kreatif di kelas kontrol berkategori cukup baik.

\section{Respons Guru dan Siswa}

Respons guru setelah menggunakan perangkat pembelajaran SETS adalah sangat baik. Sedangkan siswa memberikan respons yang baik pada pembelajaran menggunakan perangkat pembelajaran SETS.

\section{Pembahasan}

Berdasarkan hasil revisi dari ahli, dan temuan pada saat uji coba di lapangan, dihasilkan produk akhir. Kajian produk akhir pengembangan perangkat pembelajaran ini merupakan hasil konfirmasi antara kajian teori dan temuan penelitian sebelumnya. Perangkat pembelajaran berupa RPP dan LKS yang dikembangkan dalam penelitian ini layak untuk digunakan menurut ahli materi dan ahli pembelajaran. Perangkat pembelajaran tersebut mempunyai 
konsep yang jelas, disajikan dengan petunjuk yang jelas, dan materi yang digunakan sesuai dengan kompetensi inti dan kompetensi dasar.

Perangkat pembelajaran yang berupa RPP disusun dengan memperhatikan komponen-komponen yang tertuang dalam Permendikbud Nomor 103 Tahun 2014 tentang Pembelajaran pada Pendidikan Dasar, yaitu identitas, rumusan indikator, materi, media dan sumber belajar, metode pembelajaran, kegiatan pembelajaran, adanya LKS untuk membantu kemandirian belajar siswa, penilaian hasil belajar untuk mengukur ketercapaian belajar siswa, memperhatikan penggunaan bahasa, serta kesesuaian dengan tujuan yang akan ditingkatkan.

Pembelajaran dirancang untuk mengaktifkan siswa melalui kegiatan diskusi kelompok, tanpa adanya persaingan antar siswa maupun antar kelompok. Pemilihan pendekatan SETS juga sesuai dengan karakteristik siswa sekolah dasar, bahwa siswa membutuhkan bimbingan guru atau orang dewasa terutama untuk membimbingnya dalam belajar. Selain itu, adanya kegiatan diskusi dan kerja sama antara dua siswa atau lebih dalam memecahkan masalah secara bersama-sama, adanya tujuan yang ingin dicapai, rasa saling peduli antar teman, serta tidak adanya kompetisi belajar yang ada adalah kegiatan saling belajar, sehingga dapat menciptakan suasana belajar yang nyaman bagi siswa. Jadi penggunaan pendekatan SETS dalam pembelajaran sangat cocok dan sesuai dengan karakteristik siswa SD.

Inti dari pendekatan SETS adalah adanya komunikasi antar siswa, untuk saling berbagi pengetahuan. Siswa yang pandai membantu siswa yang kurang pandai. Dengan rancangan kegiatan pembelajaran tersebut dapat meningkatkan kemampuan berpikir kreatif. Pembelajaran dengan menggunakan pendekatan SETS membuat para siswa merasa nyaman dalam beraktivitas secara berpasangan atau dalam sebuah kelompok belajar, sehingga mereka dapat 
bekerja secara bersama-sama. Siswa juga nyaman dengan kegiatan yang bisa dilakukannya dengan menggunakan berbagai kemampuan yang ada (seperti melakukan penelitian dan melaporkannya) dibandingkan kegiatan pembelajaran yang berulang-ulang dan membosankan (seperti latihan soal). Dalam kegiatan pembelajaran seperti ini, siswa diberi kebebasan berkreasi menghasilkan produk, mengidentifikasinya bersama, lalu mempresentasikannya di depan kelas.

Pendekatan SETS merupakan pendekatan yang fokus mengenai cara membuat siswa agar dapat melakukan penyelidikan, berarti memberi kesempatan kepada siswa untuk mengembangkan lebih jauh pengetahuan yang diperoleh untuk menyelesaikan masalah-masalah yang diperkirakan akan timbul di sekitar kehidupan sehari-hari dan sesuai dengan pengalaman yang dialami siswa. Pendekatan SETS memberi tempat yang dapat mencukupi para guru dan siswa untuk menuangkan kemampuan berkreasi dan berinovasi. Proses Pendekatan SETS dilakukan dengan cara guru memberikan materi pembelajaran. Materi tersebut tidak hanya mengkaji dari sisi ilmu pengetahuan saja tetapi juga mengkaji pengaruhnya bagi lingkungan, kehidupan sosial manusia, dan penerapannya dalam bidang teknologi.

Nurcahyani N., Mulyani B., \& Mahardiani L., menjelaskan bahwa pendekatan SETS selalu menghubungkan proses belajar mengajar dengan kejadian nyata yang dijumpai dalam kehidupan sehari-hari (bersifat kontekstual) dan komprehensif (terintegrasi diantara keempat komponen SETS, guru dapat menghubungkan konsep-konsep Ilmu Pengetahuan Alam (IPA) yang diajarkan dengan permasalahan-permasalahan yang terjadi di lingkungan masyarakat sehingga pembelajaran yang dilakukan di sekolah bermanfaat bagi masyarakat. ${ }^{8}$

\footnotetext{
${ }^{8}$ Nurcahyani, N., Mulyani, B., \& Mahardiani, L., Efektivitas Metode Pembelajaran STAD Berbasis SETS Berbantuan Macromedia Flash Terbadap Prestasi Belajar Siswa Pada Materi Pokok Perubahan Fisika Dan Kimia Kelas VII Semester Genap SMP Negeri 14 Surakarta Tabun Ajaran 2010/2011. Jurnal Pendidikan Kimia, Program Studi Pendidikan Kimia Universitas Sebelas Maret, 2012. 1, 20
} 
Pendekatan pembelajaran SETS dapat menghubungkan kehidupan dunia nyata siswa sebagai anggota masyarakat dengan kelas sebagai ruang belajar IPA. Proses pendekatan ini dapat memberikan pengalaman belajar bagi siswa dalam mengidentifikasi potensi masalah, mengumpulkan data yang berkaitan dengan masalah, mempertimbangkan solusi alternatif, dan mempertimbangkan konsekuensi berdasarkan keputusan tertentu.

Pendekatan SETS dalam pembelajaran yang dimaksudkan untuk mengetahui, dimana IPA dapat menghasilkan teknologi untuk perbaikan lingkungan sehingga bermanfaat bagi masyarakat. Yager, R.E., Hakan Akcay menjelaskan bahwa: Generating ideas for use of science concepts in new situations Using creativity skills, including questioning, proposing possible explanations Devising tests for the validity of the explanations generated Using community resources Conversing about science at bome Taking actions in the community as a result of science study. ${ }^{9}$

Siswa akan lebih mudah memahami pembelajaran materi IPA bila dikaitkan dengan pengetahuan, sikap, dan keterampilan. Tujuannya adalah agar siswa dapat fokus mempelajari konsep dasar yang berkaitan dengan isi pelajaran, dapat mengajarkan, dan melatih keterampilan yang didapat dalam berbagai bidang. Sebagaimana penjelasan yang sama disampaikan oleh Dilek E. A. : "STSE acquisitions focused on three main dimensions: (1) nature of science and technology; (2) relations between Science and Technology and; (3) social and environmental context of science and technology". ${ }^{10}$

Pendekatan SETS lebih mengutamakan keterkaitan antara topik bahasan dengan kehidupan sehari-hari siswa, dalam arti siswa mengambil dan

${ }^{9}$ Yager, R.E., \& Hakan, AComparison of Student Learning Outcomes in Middle School Science Classes with an STS Approach and a Typical Textbook Dominated Approach, RMLE Online, 31, 2008, 15.

${ }^{10}$ Dilek, E. A., Turkish Teacher Opinions About Science, Technology, Society, Enviroment Acquisitions In Science And Technology Course Curriculum, Journal of Baltic Science Education, 13, 2014, 217. 
memperhatikan masalah yang ada di lingkungan yang bersinggungan langsung dengan siswa. Hal tersebut sesuai dengan tujuan dari pendekatan SETS menurut Yaseen, M.Y., \& Subahan,T.M., bahwa: This allows students to relate the scientific concepts to problems they may have already encountered, makes science curricula to be closely related to their life in order to strengthen their understanding of the concepts, reaction of SETS, and develops self learning in the future in order to be good citizens and have the ability to make use of science as well as technology to help contribute to their societies. SETS science content is dealing mainly with social issues that connect science with a societal problem; it derived from students constructing problems and investigations from real-world issues and concerns. Therefore, the starting point for SETS content is a list of possible social issues that might interest the students. ${ }^{11}$

Dari penjelasan di atas bahwa pendekatan pembelajaran SETS juga bertujuan untuk membantu siswa mengetahui IPA, perkembangannya dan bagaimana perkembangan IPA dapat mempengaruhi lingkungan, teknologi, dan masyarakat secara timbal balik. Selain itu pendekatan SETS juga bertujuan agar siswa mengetahui cara menyelesaikan masalah-masalah yang timbul akibat berkembangnya masalah yang berkaitan dengan masyarakat.

Pendekatan SETS diharapkkan dapat menjadikan siswa mengerti unsurunsur utama SETS dan keterkaitan antar unsur-unsur tersebut pada saat mempelajari IPA. Dengan kata lain, diperlukan pemikiran yang kreatif untuk belajar setiap elemen dari pendekatan ini dengan memperhatikan berbagai keterhubungan antara unsur-unsurnya.

Hasil uji coba lapangan operasional menunjukkan peningkatan kemampuan berpikir kreatif setelah mengikuti pembelajaran dengan

11 Yaseen, M.Y., \& Subahan T.M., The Ranking of Science, Technology and Society (STS) Issues by Students and Physics Teachers in Secondary School, (Yemen University Kebangsaan Malaysia, 2, 2012), 47. 
menggunakan perangkat pembelajaran SETS. Selain itu, hasil penelitian juga menunjukkan adanya perbedaan antara kelas eksperimen yang mendapat perlakuan berupa penggunaan perangkat pembelajaran SETS dengan kelas kontrol yang tidak menggunakan perangkat pembelajaran hasil pengembangan tersebut. Perangkat pembelajaran yang berupa RPP dan LKS terbukti layak dan efektif untuk meningkatkan kemampuan berpikir kreatif.

\section{Simpulan}

Perangkat pembelajaran SETS yang dikembangkan untuk meningkatkan kemampuan berpikir kreatif siswa dinilai layak untuk digunakan menurut ahli materi dan ahli pembelajaran dengan nilai sangat valid. Perangkat pembelajaran SETS terbukti dapat meningkatkan kemampuan berpikir kreatif siswa kelas IV SD. Berdasarkan hasil uji coba lapangan operasional menunjukkan bahwa ada perbedaan yang signifikan terhadap kemampuan berpikir kreatif antara siswa yang mengikuti pembelajaran dengan menggunakan perangkat dan siswa yang mengikuti pembelajaran tanpa menggunakan perangkat pembelajaran hasil pengembangan.

Pengembangan perangkat pembelajaran SETS untuk meningkatkan kemampuan berpikir kreatif siswa kelas IV SD sudah diuji kelayakan dan keefektifannya. Oleh karena itu, disarankan kepada guru untuk: (1) menggunakan perangkat pembelajaran ini sebagai pedoman pelaksanaan pembelajaran yang dapat meningkatkan kemampuan berpikir kreatif, dan (2) menggunakan produk perangkat pembelajaran ini dengan penyesuaian pada karakteristik siswa dan lingkungan sekitar sekolah.

\section{Daftar Pustaka}

Akbar, S.. 2013, Instrumen Perangkat Pembelajaran. Bandung : PT Remaja Rosdakarya.

Ar-Riayah : Jurnal Pendidikan Dasar vol.1 no. 01, 2017

STAIN Curup - Bengkulu I p ISSN 2580-362X; e ISSN 2580-3611 
Bernadete, I.D.R., 2009, Science, Technology, Society and Environment (STSE) Approach in Environmental Science for Nonscience Students in a Local Culture. Journal of Higher Education Research Science and Technology Section, 6.

Dilek, E. A., 2014, Turkish Teacher Opinions About Science, Technology, Society, Enviroment Acquisitions In Science And Technology Course Curriculum, Journal of Baltic Science Education, 13.

Mariana \& Alit, M., 2000, Suatu Tujuan Tentang Hakikat Pendekatan Science, Technology, and Society dalam Pembelajaran Sains, Pelangi Pendidikan, 2.

Miles, M.B., Huberman, A.M., \& Saldana, J., 2014, Qualitative Data Analysis : A Methods Sourcebook, Los Angeles: Sage.

Nurcahyani, N., Mulyani, B., \& Mahardiani, L., 2012, Efektivitas Metode Pembelajaran STAD Berbasis SETS Berbantuan Macromedia Flash Terbadap Prestasi Belajar Siswa Pada Materi Pokok Perubahan Fisika Dan Kimia Kelas VII Semester Genap SMP Negeri 14 Surakarta Tabun Ajaran 2010/2011, Jurnal Pendidikan Kimia, Program Studi Pendidikan Kimia Universitas Sebelas Maret,1.

Peraturan Menteri Pendidikan Nasional Republik Indonesia Nomor 41 Tahun 2007 Tentang Standar Proses Untuk Satuan Pendidikan Dasar Dan Menengah.

Permendikbud Nomor 103 Tahun 2014 tentang Pembelajaran pada Pendidikan Dasar.

Stephen, A.M., \& Megan, D., 2012, The Impact of an STS Approach on the Development of Aspects of Scientific Literacy of Grade 10 Learners, Paper presented at SAARMSTE Conference, 1.

Undang-Undang Republik Indonesia Nomor 20 Tahun 2003 Tentang Sistem Pendidikan Nasional.

Yager, R.E., \& Hakan, A., 2008, Comparison of Student Learning Outcomes in Middle School Science Classes with an STS Approach and A Typical Textbook Dominated Approach, RMLE Online, 31. 
Yaseen, M.Y., \& Subahan, T.M., 2012, The Ranking of Science, Technology and Society (STS) Issues by Students and Physics Teachers in Secondary School, Yemen University Kebangsaan Malaysia, 2.

Gall, M. D., Gall, J. P., \& Borg, W. R., 2007., An Introduction to Educational Design Research. East, $129 . \quad$ Retrieved from www.slo.nl/organisatie/international/publications. 